\title{
ПРЕДСТАВНИЦТВО ВІЙСЬКОВИХ У СКЛАДІ УКРАЇНСЬКОЇ ЦЕНТРАЛЬНОЇ РАДИ
}

У статті розглядаються військові та військово-політичні аспекти функціонування вищих державних органів влади в період діяльності Української Центральної Ради, кількісні та якісні показники членства в цій державницькій інституції представників військових кіл - військових підрозділів, військових громадських організацій, окремих військовослужбовців, з'ясовуються обставини набуття ними статусу депутатів УЦР, визначається ефективність їхньої роботи в складі УЦР різних скликань. У дослідженні подаються біографічні відомості найбільш яскравих представників українського війська.

Ключові слова: Українська революція, Українська Центральна Рада, військово-політична ситуація, українське військо, Всеукраїнський військовий з’їзд.

Постановка проблеми та ї̈ актуальність. Серед багатьох сторінок національної історії, які в останні кілька років набули нового змісту, чільне місце займають дослідження, пов'язані 3 військовими та військово-політичними аспектами доби Української революції. При цьому слід зауважити, що ці процеси активізувалися в період відзначення столітнього ювілею тих революційних подій. Дослідники, відкриваючи й публікуючи невідомі донині документи, переосмислюють значну частину висновків, зроблених попередніми авторами.

Пожвавили дискусії навколо військових і військо-політичних подій доби Української революції 1917-1921 рр. й сумнозвісні події на Сході України, пов'язані 3 російсько-українською війною, спроби віднайти в національній історії елементи героїчного військового минулого українців, зразки воєнної звитяги національних військових підрозділів.

Принагідно зауважимо, що військова складова в добу Української революції відігравала важливе значення для становлення національної державності. До цього спричинило кілька факторів. Насамперед те, що на початок революційних подій 1917 р. більшість територій українських губерній були

Дем'янюк Олександр Йосипович, доктор історичних наук, професор, проректор 3 науково-педагогічної роботи та моніторингу якості освіти Волинського інституту післядипломної педагогічної освіти, м. Луцьк.

() Дем'янюк О.Й., 2018 
втягнуті у воєнне протистояння на фронтах Першої світової війни. Об'єктивно склалося, що військові-українці, які перебували на території західних українських губерній у складі російської та австрійської імперських армій, стали найбільш радикальним революційним елементом. Не дивно, що керівники молодої української державності побоювалися людей зі зброєю й робили все, аби знівелювати їхній вплив на військово-політичні процеси в Україні.

Тому на першому етапі Української революції (доба Української Центральної Ради (УЦР) політики вищого ешелону української влади намагалися віддалити військових від державного управління, зректися боєздатної армії перед побоюванням за своє політичне майбутнє. Попри це роль військових у національному державотворенні була досить помітною. Участь представників військових частин, які перебували на українських теренах, у діяльність УЦР яскраве тому підтвердження.

Аналіз попередніх досліджень і публікацій. Задля об'єктивності висвітлення сфальсифікованих сторінок вітчизняної історії до їх вивчення щоразу долучаються нові дослідники. Окреслюючи загальну парадигму революційних подій 1917-1921 рр., вітчизняні вчені вивчають окремі військові та військовополітичні процеси, які протікали на підвладних українському уряду територіях колишніх Російської та Австро-Угорської імперій. Проте детального дослідження участі делегатів військових частин у роботі УЦР нами не виявлено. Попри це на увагу заслуговують праці В. Верстюка, Т. Осташка (про діячів УЦР) [1], Я. Тинченка (про офіцерський корпус УНР) [2].

Мета та завдання дослідження. 3 огляду на стан наукової розробки запропонованої для дослідження проблеми розглянемо кількісні та якісні показники членства Української Центральної Ради 3-посеред військового середовища, з'ясуємо обставини набуття ними статусу депутатів УЦР, визначимо ефективність їхньої роботи в складі УЦР різних скликань.

Виклад основного матеріалу дослідження. Насамперед кілька слів про статусність Української Центральної Ради (УЦР). 3 березня 1917 р. $з$ ініціативи Товариства українських поступовців у київському клубі «Родина» відбулися збори представників 
українських організацій. Результатом цього зібрання стало утворення національного коаліційного органу - Української Центральної Ради, завданням якої було скликати Всеукраїнський Національний конгрес. Делегати Національного конгресу мали остаточно вибрати Українську Центральну Раду як постійний український парламент [3].

Тим часом прийнято вважати початком діяльності цього представницького органу 7 березня 1917 р., коли відбулися вибори керівництва УЦР. Відтоді Українська Центральна Рада поступово набирала політичної ваги й ставала керівним органом українського національного руху. Тогочасний склад УЦР налічував 94 особи [1, с. 206-208] й працював упродовж місяця (7 березня - 7 квітня 1917 р.)

До цього першого складу УЦР увійшли представники військових кіл - військовослужбовці підрозділів російської армії, які дислокувалися на території українських губерній, члени військових громадських організацій, які навесні 1917 р. зароджувалися в Києві та містах, де дислокувалися найбільші військові гарнізони з чисельною перевагою військових-українців.

Серед таких знаходимо: Івана Авраменка, солдата, представника Київського військового гарнізону; Лева Гана, полковника, співзасновника Українського військового клубу ім. гетьмана Павла Полуботка, голову Українського військового організаційного комітету, близького соратника й товариша М. Міхновського; Микиту Глинського, полковника, військово-політичного та громадського діяча, члена Українського військового клубу ім. гетьмана Павла Полуботка; Запорожця, поручика, члена Українського військового клубу ім. гетьмана Павла Полуботка; Сергія Колосова (Колоса), солдата, члена Українського військового клубу ім. гетьмана Павла Полуботка; Василя Матяшевича, підполковника (згодом - генерал-хорунжий Армії УНР), представника Київського військового гарнізону; Миколу Міхновського, поручника, співзасновника і голову Українського військового клубу ім. гетьмана Павла Полуботка, ініціатора створення Першого українського козацького полку ім. гетьмана Богдана Хмельницького; Піщанського, полковника, члена Українського військового клубу ім. гетьмана Павла Полуботка.

У цьому списку найбільше представників Українського військового клубу ім. гетьмана Павла Полуботка. Тому є необхідність 
хоча би фрагментарно зупинитися на засадах діяльності цієї організації. Створено товариство було 16 березня 1917 р. в Києві, переважно на базі військових-українців місцевого гарнізону (під час наради військовиків цього гарнізону). Головні зусилля керівництвом клубу були сконцентровані на створенні української національної армії. Для цього було утворено Український військовий організаційний комітет, який очолив полковник М. Глинський.

Відразу кілька представників клубу увійшли до першого складу Української Центральної Ради. Втім, їхні самостійницькі погляди на побудову української національної армії не знайшли підтримки у більшості членів УЦР. Представники соціалістичних кіл в УЦР не дивилися далі федеративних відносин із Російською державою, заперечуючи будь-яку потребу в національній армії.

Задля активізації національного руху частина членів Українського військового клубу ім. гетьмана Павла Полуботка на початку липня 1917 р. ініціювала виступ Українського полку ім. гетьмана Павла Полуботка в Києві. Бойове протистояння 4-5 липня завершилося роззброєнням полку силами штабу Київського військового округу та Першого українського козацького полку ім. гетьмана Богдана Хмельницького. М. Міхновського й частину полуботківців було відіслано на Румунський фронт. Однак Український військовий клуб ім. гетьмана Павла Полуботка продовжував свою діяльність щонайменше до січня 1918 р.

Всеукраїнський Національний конгрес (6-8 квітня 1917 р.) був, без перебільшення, найзначнішою подією весни 1917 р. На цьому форумі відбувся процес конституціювання Української Центральної Ради, яка отримала статус представницького органу влади українського народу. Обрання персонального складу УЦР фактично забезпечило представництво інтересів територіальних громад, політичних партій та національних меншин у найвищому державному органі [4, с. 100].

У день завершення роботи Національного конгресу відбулися Перші загальні збори, під час роботи яких було перевірено i затверджено загальний список членів УЦР, сформовано виконавчий орган інституції - Комітет Української Центральної Ради. Впродовж існування УЦР відбулося дев'ять загальних зборів (останні - 15-25 січня 1918 р.).

Знаходимо у тому списку представників військових частин i українських військових громадських організацій, які були 
членами УЦР до початку роботи Всеукраїнського Національного конгресу, - солдат І. Авраменко, підполковник В. Матяшевич (обидва - Київський військовий гарнізон), полковник Л. Ган (Український військовий організаційний комітет), полковник М. Глинський, поручик Запорожець, солдат С. Колосов, поручник М. Міхновський, полковник Піщанський (усі - Український військовий клуб ім. гетьмана Павла Полуботка). Окрім того, до складу УЦР 8 квітня 1917 р. було введено: солдата С. Березняка (військова громада м. Кременця), солдата Васюка (військова рада м. Виборга), військового лікаря О. Крупського (Балтійський флот, м. Кронштадт), прапорщика Куща (Одеський військовий гарнізон), солдата Овраменка (Київський військовий гарнізон) (можливо, щзо солдат Авраменко $і$ солдат Овраменко від Київського військового гарнізону - ие одна особа. - О.Д.), Пелішенка (Одеський флотський гарнізон), А. Вовченка (8-1 залізничний батальйон) [1, с. 208-211].

Наступне розширення кількісного складу Української Центральної Ради представниками військового середовища пов'язане з роботою Першого всеукраїнського військового з'їзду (5-8 травня 1917 р.). Окрім того, що під час роботи з’їзду були підняті політичні питання, зокрема, автономія України, відносини 3 Тимчасовим урядом Росії та Радою робітничих і солдатських депутатів, було кооптовано до складу УЦР нових членів. Перший всеукраїнський військовий з'їзд обрав Український генеральний військовий комітет (УГВК) (голова С. Петлюра), який увійшов до УЦР в складі вісімнадцяти осіб [5, с. 65]. Цей орган до своєї реорганізації 20 листопада 1917 р. у Генеральне секретарство військових справ УЦР виконував керівні функції українського військового руху.

Персонально після завершення Першого всеукраїнського військового з'їзду від УГВК до складу Української Центральної Ради увійшли: цивільні особи, політики С. Петлюра та В. Винниченко, генерал-майор М. Іванів, полковники І. Луценко, О. Пилькевич, В. Павленко, підполковники Ю. Капкан, В. Поплавко, поручники А. Чернявський, М. Міхновський (вже був членом УЦР від Украӥнського військового клубу ім. гетьмана Павла Полуботка.-О. Д.), капітани А. Певний, В. Потішко, М. Полозов, Ф. Селецький, військовий урядник I. Горемика-Крупчинський, солдати С. Гражан, Д. Ровинський, матрос С. Письменний [1, с. 221]. 
Після Другого всеукраїнського військового з’їзду (5-10 червня 1917 р.) до складу УГВК, а відтак і до складу Української Центральної Ради увійшло ще десять осіб: генерал-майор Л. Кондратович, полковник О. Жуковський, підполковники В. Матяшевич (вже був членом УЦР від Київського військового гарнізону - О.Д.), О. Сливинський, капітан Г. Глібовський, поручники В. Кедровський, М. Левицький, П. Скрипчинський, прапорщик С. Білецький, солдат С. Колос (Колосов) (ймовірно вже був членом УЦР від Украӥнського військового клубу ім. гетьмана Павла Полуботка. - О. Д.) [6].

Наприклад, капітан російської армії Георгій Глібовський на Другому всеукраїнському військовому з'їзді обраний до УГВК, де виконував обов'язки начальника канцелярії. Брав участь у роботі УЦР. У листопаді 1917 р. Г. Глібовський став помічником командувача Київським військовим округом [9, с. 107]. Генералмайор Лука Кондратович також на Другому всеукраїнському військовому з'їді обраний до УГВК, де обійняв посаду начальника комісії спецслужб. Під час зборів УЦР виступав проти антимілітарних поглядів значної частини делегатів [9, с. 211-212]

Найповніший перелік військовослужбовців, які стали членами Української Центральної Ради, здебільшого після Першого і Другого всеукраїнських військових з'їздів, знаходимо в протоколі мандатної комісії Шостих загальних зборів УЦР від 8 серпня 1917 р. Так, Всеукраїнська рада військових депутатів представлена 132 членами, Український генеральний військовий комітет 26 особами. Із цих 132 військовиків $60 \%$ складали солдати, 40\% офіцери [7, с. 44]. У тогочасній УЦР знаходимо широкий спектр фронтів, армій, військових частин, гарнізонів. Найбільше від підрозділів Південно-Західного фронту.

Так, серед військових представників в УЦР ПівденноЗахідний фронт репрезентували: поручник П. Лісовський, прапорщик Т. Бабій, солдат С. Березняк (11-та армія); підпоручик Т. Калган, унтер-офіцер С. Іванченко, єфрейтор І. Довгопольський (7-ма армія); єфрейтор Я. Левченко, солдат Н. Наконечний (8-ма армія) та інші. 3 Румунського фронту: прапорщик В. ЗаїченкоЖадько, прапорщик С. Слюсарчук, солдат Д. Копійка, урядник В. Рябчинський (4-та армія); підпоручик Г. Лисенко, підпоручик 
C. Надобко, підпоручик Д. Околот-Околотенко, фейєрверкер С. Козимчук (9-та армія) та інші. Із Західного фронту: поручник П. Назаренко, прапорщик М. Масюк, солдат Д. Юда, солдат К. Прокопович (10-та армія); поручик 3. Сухий (3-тя армія) та інші. Від Північного фронту: поручник Я. Стовбуненко-Заїченко, прапорщик Ф. Котляр, старший унтер-офіцер I. Набоков (1-ша армія); поручник О. Халабуденко (5-та армія); поручник А. Пащенко-Пасько, підпоручик А. Савон (12-та армія). Із Кавказького фронту: підпоручик П. Куцяк-Чалий (22- й стрілецький Кавказький полк).

Були представники й військових округів. І3 Київського військового округу: прапорщик М. Врублевський, прапорщик П. Герасименко, прапорщик Г. Касяненко, старший унтер-офіцер Н. Линник, солдат А. Гусенко, фельдшер Я. Зозуля; з Петроградського військового округу: старший унтер-офіцер П. Войтенко, старший унтер-офіцер П. Мірошник, старший унтер-офіцер I. Ярошенко, солдат С. Мельник, із Московського військового округу: капітан М. Самойлович, прапорщик К. Бойченко, вахмістр В. Коробко, єфрейтор Д. Личко, солдат П. Меюс; 3 Одеського військового округу: прапорщик І. Карпенко, молодший унтер-офіцер Ю. Коваленко, військовий технік Г. Знахаренко, фельдшер I. Іванов; 3 Казанського військового округу: підпоручик С. Паночині, прапорщик В. Линник, солдат I. Марченко, лікар козацької дивізії В. Кекало; з Омського військового округу: прапорщик I. Ткалич; 3 Двінської військової округи: підпоручик М. Рашавець, прапорщик А. Батієвський; тощо.

За військовою квотою увійшли до складу УЦР представники запасних частин, гарнізонів, флотів, шпиталів: солдат М. Авдієнко (розвантажувальний батальйон, м. Петроград), солдат С. Балабан (12-та хімічна команда), солдат О. Геймайзе (2-й запасний саперний батальйон, м. Київ), урядник П. Демерлій (Управління крайового комісара Галичини і Буковини), підпоручик С. Дзятина (запасна батарея 4-го стрілецького батальйону), солдат К. Дубинський (конвойна команда гарнізону м. Кременчук), матрос І. Дудкін (крейсер «Мітава», Балтійський флот), старший унтер-офіцер К. Карабчевський (1-й український розподільчий пункт), фельдшер Л. Кизима (Миколаївський військовий шпиталь, м. Петроград), старший писар Т. Кондрашко 
(Управління коменданта залізничної станції Чернівці), урядовець Т. Корнієнко (8-й запасний кавалерійський полк, м. Слизаветград), фельдшер Г. Крохмаль (101-й головний евакуаційний пункт), солдат В. Лещенко (2-га школа прапорщиків, м. Казань), солдат К. Хідченко (107-ма команда одужуючих Лубенського гарнізону), урядник О. Чапківський (арсенал, м. Москва) тощо.

Таке розмаїття військового фаху, військових підрозділів, географії розташування військових частин не сприяло ефективній участі військовослужбовців - членів Української Центральної Ради в роботі цього державного органу. За підрахунками професора В. Верстюка, «реально в роботі Центральної Ради брали участь лише 100 членів Ради військових депутатів, решта повернулася в свої частини і втратила зв'язок із Києвом» $[8$, c. 22].

Щоправда, частина військовослужбовців активно включилася в політичну діяльність та державотворчу роботу УЦР. Так, солдат Михайло Авдієнко (розвантажувальний батальйон, м. Петроград) прибув до Києва для участі в роботі Всеукраїнського національного конгресу, де був обраний до його президії. Ще перед тим був одним із організаторів 20-тисячної української маніфестації в Петрограді, очолював збройний виступ Волинського полку. Під час роботи Першого всеукраїнського військового з'їзду був обраний до Всеукраїнської ради військових депутатів й звідти кооптований до складу УЦР. Як представник фракції УСДРП в УЦР був делегований до Малої ради [1, с. 62-63].

Ветеринарний лікар 9-го армійського Гренадерського полку Кость Вротновський-Сивошапка брав участь у Першому всеукраїнському військовому з'їді, де був обраний до Всеукраїнської ради військових депутатів, увійшов до складу УЦР. Будучи членом Української трудової партії, був залучений до роботи в Малій раді. Тут брав участь в діяльності комісій УЦР у справах переговорів із національними меншинами, розробляв проект статуту автономії України.

Солдат Осип Геймайзе (2-й запасний саперний батальйон, м. Київ) від початку Української революції пропагував соціалдемократичні ідеї серед своїх колег. Був делегатом Другого всеукраїнського військового з'їзду, під час роботи якого увійшов до Всеукраїнської ради військових депутатів (член постійної президії). Працюючи в УЦР, увійшов до складу Малої ради за 
списком УСДРП, де працював у комісії з підготовки проекту автономії України $[1$, с. 81]. Ще можна згадати кілька десятків військовиків, які брали активну участь у роботі Української Центральної Ради, Малої ради та інших структур УЦР підполковник Юрій Капкан, капітан Михайло Полозов, поручник Микола Міхновський, прапорщик Юрій Тютюнник, солдат Сергій Колос, фейєрверкер Антін Постоловський, фельдшер Яків Зозуля, фельдшер Іван Іванов та інші.

Отож, військове представництво в складі Української Центральної Ради не було постійним. Воно зростало через кооптування до УЦР членів Всеукраїнської ради військових депутатів, Українського генерального військового комітету, обраних під час роботи Першого та Другого всеукраїнських військових з'їздів. У кількісних показниках представництво військових у складі УЦР сягнуло 158 осіб. Щоправда, участь в роботу цієї інституції брали в середньому 100 осіб. Найефективніші військовики залучалися до роботи в Малій раді, комітетах УЦР, постійних і тимчасових комісіях.

1. Верстюк В. Діячі Української Центральної Ради. Біографічний довідник / В. Верстюк, Т. Осташко. К. : [б. в.], 1998. -256 с.

2. Тинченко Я. Офіцерський корпус Армії Української Народної Республіки (1917-1921). Книга I : Наукове видання / Я. Тинченко. - К. : Темпора, 2007. 536 с.; Тинченко Я. Офіцерський корпус Армії Української Народної Республіки (1917-1921). Книга II : Наукове видання / Я. Тинченко. - К. : Темпора, 2011. $424 \mathrm{c}$.

3. Антонович Д. Довкола засновин Центральної Ради / Д. Антонович // Діло. - 1937. - 27 березня.

4. Дем'янюк О. Й. Військово-політичні аспекти розвитку Волинської губернії у 1914-1921 роках : монографія / О. Й. Дем’янюк. - Луцьк:- ПВД «Твердиня», 2011. $-320 \mathrm{c}$.

5. Дем'янюк $O$. Волинь в Українській революції: доба Української Центральної Ради : монографія / Олександр Дем'янюк. - Луцьк : ПП Іванюк В. П., 2018. - 232 с.

6. Гай-Нижник П. П. Генеральний Військовий Комітет Український [Електронний ресурс] / П. П. ГайНижник // Енциклопедія сучасної України. - Режим доступу: http://esu.com.ua/search_articles.php?id=29054. 
7. Щусь О. Й. Всеукраїнські військові з'їзди / О. Й. Щусь. - К. : Ін-т історії України АН України, 1992. $86 \mathrm{c}$.

8. Верстюк В. Ф. Склад і структура Української Центральної Ради / В.Ф. Верстюк // Проблеми вивчення історії Української революції 1917-1921 років. - 2009. Вип. 4. - С. 5-30.

9. Тинченко Я. Офіцерський корпус Армії Української Народної Республіки (1917-1921). Книга I : Наукове видання / Я. Тинченко. - К. : Темпора, 2007. - 536 с.

Надійшла до редакції 07.09. 2018 р.

\section{Demianiuk O. J. \\ REPRESENTATION OF MILITARY CIRCLES IN THE UKRAINIAN CENTRAL COUNCIL}

In the article the author considers the military and military-political aspects of the functioning of the higher state authorities in the period of the Ukrainian Central Council and enlightens quantitative and qualitative indicators of the membership of representatives of military circles (military units, military civil organizations, military officers) in it. Additionally, the conditions of obtaining the membership in the Ukrainian Central Council by people from military circles are revealed as well as the efficiency of the latter's work is determined. The article also contains biographical information concerning the brightest people of Ukrainian army.

Keywords: Ukrainian revolution, Ukrainian Central Council, military-political situation, Ukrainian army, All-Ukrainian military conference. 